\title{
Waterglass impregnation of municipal solid waste incineration bottom ash applied as sand replacement in mortars
}

Citation for published version (APA):

Caprai, V., Lazaro, A., \& Brouwers, H. J. H. (2019). Waterglass impregnation of municipal solid waste incineration bottom ash applied as sand replacement in mortars. Waste Management, 86, 87-96.

https://doi.org/10.1016/j.wasman.2019.01.025

\section{Document license:}

TAVERNE

DOI:

10.1016/j.wasman.2019.01.025

Document status and date:

Published: 01/03/2019

\section{Document Version:}

Publisher's PDF, also known as Version of Record (includes final page, issue and volume numbers)

\section{Please check the document version of this publication:}

- A submitted manuscript is the version of the article upon submission and before peer-review. There can be important differences between the submitted version and the official published version of record. People interested in the research are advised to contact the author for the final version of the publication, or visit the $\mathrm{DOI}$ to the publisher's website.

- The final author version and the galley proof are versions of the publication after peer review.

- The final published version features the final layout of the paper including the volume, issue and page numbers.

Link to publication

\section{General rights}

Copyright and moral rights for the publications made accessible in the public portal are retained by the authors and/or other copyright owners and it is a condition of accessing publications that users recognise and abide by the legal requirements associated with these rights.

- Users may download and print one copy of any publication from the public portal for the purpose of private study or research.

- You may not further distribute the material or use it for any profit-making activity or commercial gain

- You may freely distribute the URL identifying the publication in the public portal.

If the publication is distributed under the terms of Article 25fa of the Dutch Copyright Act, indicated by the "Taverne" license above, please follow below link for the End User Agreement:

www.tue.nl/taverne

Take down policy

If you believe that this document breaches copyright please contact us at:

openaccess@tue.nl

providing details and we will investigate your claim. 


\title{
Waterglass impregnation of municipal solid waste incineration bottom ash applied as sand replacement in mortars
}

\author{
V. Caprai* ${ }^{*}$ A. Lazaro, H.J.H. Brouwers \\ Department of Built Environment, Eindhoven University of Technology, Eindhoven 5600 MB, the Netherlands
}

\section{A R T I C L E I N F O}

\section{Article history:}

Received 18 September 2018

Revised 16 January 2019

Accepted 17 January 2019

Available online 29 January 2019

\section{Keywords:}

Impregnation treatment

Sodium silicate

Municipal solid waste incineration bottom ash

Lightweight concrete

Secondary building material

\begin{abstract}
A B S T R A C T
Incineration has been recognized as one of the most applied strategies for the processing of the municipal solid waste (MSW). The primary output from the incineration of the MSW is Bottom Ash (BA), whose particles are highly porous and contaminated with heavy metals, chlorides, and sulphates, limiting its application in concrete. For improving the applicability as aggregates, many porous materials are impregnated with a pozzolanic solution, easing their use as building materials. However, this treatment has never been applied to by-products like BA, and therefore the influence of a coating on the leaching behaviour of the by-products has never been investigated. This study analyses the effect of an impregnation treatment based on different sodium silicate amounts on BA particles between 1 and $2 \mathrm{~mm}$. The application of the coating lowers the pore volume of BA by 2.5 times, allowing a sand replacement up to $100 \%$ and improving the rheological behaviour of mortars till $38 \%$, compared to uncoated samples. Replacing 50 vol.\% of coated BA achieves $22 \%$ higher flexural and comparable compressive strength than the uncoated $\mathrm{BA}$ samples, thanks to the reduction of the $\mathrm{Ca} / \mathrm{Si}$ ratio in the reaction products. Finally, in the presence of the coating, the leaching of the following contaminants $\mathrm{Cl}, \mathrm{Ba}, \mathrm{Cu}, \mathrm{Zn}$ is reduced by $88,98,94$ and $97 \%$, respectively, compared to the uncoated $B A$ application. Therefore, the impregnation treatment not only favours the application of higher amounts of BA, but it also improves the final performances of the product both mechanically and environmentally.
\end{abstract}

(c) 2019 Elsevier Ltd. All rights reserved.

\section{Introduction}

Incineration has been recognised as one of the most effective strategies for the processing of the municipal solid waste (MSW) produced in many European countries. By the use of Waste-toEnergy plants (WtE), not only the waste is reduced by 90 vol.\% (Tang et al., 2016), but sustainable energy is generated by producing steam from the incineration process, and hence electricity (Ghouleh and Shao, 2018; Saffarzadeh et al., 2011). Among the residues originated, the MSWI bottom ash (BA) represents the majority of the output of the WtE plant (i.e. 80-90 wt.\%) (Yao et al., 2011; Wongsa et al., 2017). The Netherlands promote the re-use of this by-product, regulating its application as secondary building material by the Soil Quality Decree (SQD) ("Soil Quality Decree", 2015; Tang et al., 2017). However, the application of BA with this purpose is challenging. Depending on the source of the waste, BA has a variable chemical composition including slag, stone, glass, ceramic, sand and metals (Keulen et al., 2016). Moreover, high concentration of heavy metals, sulphates and chlorides

\footnotetext{
* Corresponding author.

E-mail address: v.caprai@tue.nl (V. Caprai).
}

can be detected in BA (Tang et al., 2016; "Soil Quality Decree", 2015; Tang et al., 2017). Due to the potentially harmful leaching and the risk of accelerated corrosion of steel bars in reinforced concrete, BA contamination limits its application as sand replacement. Additionally, the BA particles are usually porous, presenting a rough surface and irregular shape, caused by the quenching process after incineration (Chandler et al., 1997; Kim and Lee, 2011; Kumar et al., 2014; Lynn et al., 2016; Wongsa et al., 2016). These features often result in a great surface area and high adsorption properties, causing a high water demand, and, therefore, the reduction of the workability of the paste during the application in concrete (Li et al., 2012). In presence of porous aggregates such as recycled aggregates (RCA), several studies applied an impregnation treatment, which involves the use of a pozzolanic solutions for improving the aggregate performances (Katz, 2004; Li et al., 2009; Sallehan and Mahyuddin, 2014; Zamorano, 2016). Surface treatments based on sodium silicate solutions (waterglass, WG) (Spaeth and Djerbi-Tegguer, 2013), nano-silica (Kutcharlapati et al., 2011) or silica fume (Katz, 2004) are often beneficial as they enhance the rheological behaviour of the paste. Furthermore, the presence of silicates available for reaction improves the interfacial bond between the aggregates and the cement matrix, leading to a 
higher strength (Sallehan and Mahyuddin, 2014). In spite of the benefits of this treatment on porous materials, its application has not been investigated on MSWI BA yet. Furthermore, in those studies (Katz, 2004; Li et al., 2009; Sallehan and Mahyuddin, 2014; Zamorano, 2016), the influence of the coating on the aggregates morphology and porosity before application in mortars have not been thoroughly studied, since more attention is given to the behaviour of the final building materials. In addition, little consideration has been given on quantifying the coating amount as function of the aggregates and coating physical properties, such as density and BET surface area. The estimation of the silicate amount used for the pre-soaking is often measured after the application (by mass gain) or based on arbitrary rates. Finally, owing to the relative low content of heavy metals in alternative aggregates, the impact of the impregnation treatment on their environmental properties has not been investigated yet.

This study examines the influence of a WG coating on MSWI BA particles (1-2 mm) and their subsequent application as fine aggregates in mortars. Initially, a physical and chemical characterization in comparison with standard sand is performed. Secondly, a quantification method for the WG coating quantity is proposed based on the physical properties of the particles such as BET surface area and density. Different amounts of WG are applied on BA and the impact on the particles structure is evaluated. The optimal quantity of the coating is determined based on the maximum reduction achieved in the pore structure. Finally, the BA with the optimal coating is applied as fine aggregates and the mechanical and environmental properties of the mortars are tested based on EN 196-1 and by a reduced tank test. The effect of the coating on the performances of the mortars is analysed for different sand replacement levels (25\%, 50\%, $75 \%$ and 100 vol.\%).

\section{Experimental}

\subsection{Materials}

The MSWI bottom ash applied in this study is provided by Heros Sluskill (NL), with a particle size below $4 \mathrm{~mm}$ (FBA). By drying and sieving, the fraction $1-2 \mathrm{~mm}$ is separated and applied in this study as sand replacement. The particle size range was chosen in order to be close to standard sand that is used as a reference. BA below $1 \mathrm{~mm}$ was not used due to its high water adsorption. Henceforth, this 1-2 mm fraction will be named BA. For the mortars manufacture CEM I 52.5 R (PC) (supplied by ENCI, the Netherland) and standard sand (98\% $\mathrm{SiO}_{2}$, Norm Sand, ISO 679, EN 196-1) are applied. A commercial sodium silicate solution (waterglass, WG) is used as coating, having a composition of $27.69 \% \mathrm{SiO}_{2} \quad 8.39 \% \mathrm{Na}_{2} \mathrm{O}$ and $63.92 \% \mathrm{H}_{2} \mathrm{O}$, by mass. The purpose of employing WG is creating a uniform coating around the BA particles, which would close the porosity and maximize the availability of silicates. Nowadays, the WG environmental footprint can be reduced using alternative routes for production, such as olivine dissolution and precipitation process (Lazaro, 2014). Among the alternative sources, waste glass (Keawthun et al., 2014), rice husk ash (Cui et al., 2015; Passuello et al., 2017), biomass waste (Dodson et al., 2013), olivine nanosilica (Gao et al., 2017a) and even the bottom ash itself (Hendrix et al., 2017), contribute to a more environmental friendly production of the product.

\subsection{Methods}

Initially the BA was dried at $60{ }^{\circ} \mathrm{C}$ for $72 \mathrm{~h}$, in order to avoid mineral changes in the BA. The specific gravity of the BA was measured by a Helium pycnometer (AccuPyc II 1340), while a conventional pycnometer was used for determining the bulk density of the loose aggregates. The dry bulk density of the mortars was measured according to EN 1015-10:2006 (EN 1015-10, 2006). The determination of the water absorption was quantified by mass gain after $24 \mathrm{~h}$ in water on the oven dried uncoated BA. To obtain the saturated surface dry weight, the BA was drained into a $500 \mu \mathrm{m}$ sieve for 5 min while drying the bottom of the sieve with absorbent paper. The water absorption of loose BA in presence of the coating could not be determined, due to the solubility of the waterglass in aqueous medium. Therefore, the effectiveness of the coating for the reduction of the water absorption is indirectly measured by spread flow test on mortars. The particle size distribution (PSD) was measured by sieving using a vibratory sieve shaker (Retsch: AS 450 Basic) according to DIN EN 933-2 (EN 933-2, 1996). For the maximization of chlorides and sulphates reduction before application, a washing procedure has been applied using a dynamic washer (ESSM-30, Edmund Buhler $\mathrm{GmbH}$ ) with a liquid to solid ratio (L/S) of 3 for $60 \mathrm{~min}$ at $250 \mathrm{rpm}$ (Alam et al., 2017). The BET surface area and total pore volume were measured by nitrogen physisorption measurement (Micromeritics, Tristar II 3020V1.03). The samples are named BAn, where $\mathrm{n}$ indicates the theoretical coating thickness. Chemical characterization was performed by X-ray Fluorescence (XRF) (PANalytical Epsilon 3 range, standardless OMNIAN method) on pressed powder. Information about the morphology of the particles before and after treatment was obtained by Scanning Electron Microscopy (Phenom ProX). The analysis was performed using a backscattering electron detector with a spot size of 4.0 and $15 \mathrm{kV}$ voltage. Energy-dispersive X-ray spectroscopy (EDX) was carried out using the same settings applied during the SEM analysis. The calculation of the effective element ratios by EDX ( $\mathrm{Ca} / \mathrm{Si}$ and $\mathrm{Na} / \mathrm{Si}$ ) was done by averaging two different areas of the same sample, by using a grid of 3 by 4 points with increasing distance from the aggregate $(30,60,90,120 \mu \mathrm{m})$. An example of this grid is provided in the Appendix A. This analysis provides an overview of the effective interaction between the WG coating and the PC paste. Aware of the influence of an high alkaline environment ( $\mathrm{pH} 13-14)$ during cement hydration and knowing the acid neutralizing capacity of BA (Johnson et al., 1995), its pH development in time is evaluated reproducing the $\mathrm{L} / \mathrm{S}$ present during the mortars manufacture. The $\mathrm{pH}$ measurement during BA submersion in water for $24 \mathrm{~h}$ was performed with a VOLTCRAFT equipment (PH-100 ATC) on a system having liquid to bottom ash mass ratio of 2 . The leachates were analysed by ion chromatography (Thermoscientific Dionex ICS-1100) after filtration for the main alkali metals ( $\mathrm{Na}, \mathrm{K}, \mathrm{Ca}$, and $\mathrm{Mg}$ ).

\subsubsection{Mechanical behaviour}

The rheological behaviour of the pastes was determined using the Hägermann cone and a mortar flow table (Jolting table) according to EN 1015-3:2007-05 (EN 1015-3, 2007), using a liquid solid ratio of 0.5 independently from the replacement level. The mortars are manufactured by replacing the sand fraction of 1-2 $\mathrm{mm}$ with BA by volume for different rates $(25 \%, 50 \%, 75 \%$ and $100 \%$ named BAn_25, BAn_50,BAn_75, BAn_100, respectively where $n$ indicates the coating thickness). The mechanical performances were evaluated according to the EN 196-1 (EN 196-1, 2005), testing 3 samples for flexural and 6 for compressive strength.

\subsection{Determination of the coating amount}

In this study, a systematic approach for the determination of the WG coating amount has been investigated, taking into account factors such as BET surface area of the aggregates, density of the amorphous silicates and density of the industrial WG used. The choice of using a WG with a $\mathrm{SiO}_{2} / \mathrm{NaO}_{2}$ ratio of 3.3 originates from the necessity of having $\mathrm{pH}$ conditions lower than 12 , in order to avoid the partial dissolution of BA particles with time. The $\mathrm{pH}$ of 
the WG solution used is around 11.5 limiting this phenomenon (PQ Europe, 2004). Moreover, a low content of alkalis reduces the possible occurrence of alkali silica reaction (ASR) in cement pastes. The silicates will dissolve in presence of water, due to their soluble form, and the high $\mathrm{SiO}_{2} / \mathrm{NaO}_{2}$ ratio will limit the availability of alkali hydroxides in the pore solution, avoiding ASR. Three solutions with different WG amounts are taken into account for the coating, corresponding to three theoretical average coating thicknesses $(\mathrm{t})$ assumed as uniform $(10,15,20 \mathrm{~nm}$ named BA10, BA15 and BA20, respectively). Nevertheless, the effective coating thickness of each particle can vary as it depends on their morphology, size and porosity. The choice of those thickness values aims to minimize the WG content of the system as well as to create a coating layer which could dissolved within the interfacial transition zone of the aggregates (ITZ, transition region of $15 \mu \mathrm{m}$ thick) (Scrivener et al., 2004).

For calculating the coating thickness the following formulas are used:

$$
\begin{aligned}
& V_{S}=t * S A_{B A} \\
& m_{S}=V_{S} * \rho_{S} \\
& m_{S t o t}=m_{S} * m_{B A} \\
& \rho_{S W G}=(r / 100) * \rho_{W G} \\
& V_{W G}=m_{S t o t} * \rho_{S W G} \\
& m_{W G}=V_{W G} * \rho_{W G}
\end{aligned}
$$

where $V_{s}$ is the volume of silica $\left[\mathrm{m}^{3}\right], t$ the theoretical coating thickness $[\mathrm{m}], S A_{B A}$ the BET surface area of the BA $\left[\mathrm{m}^{2} / \mathrm{g}\right], m_{s}$ the mass of silica [ $\mathrm{g} / \mathrm{g}$ of BA], $m_{\text {stot }}$ the total mass of silica $[\mathrm{g}], \rho_{s}$ the density of amorphous silica [2.2 $\mathrm{g} / \mathrm{cm}^{3}$ ], $m_{B A}$ the mass of BA to treat [g], $\rho_{s W G}$ the density (concentration) of silica in WG solution $\left[\mathrm{g} / \mathrm{m}^{3}\right], r$ the rate of silica in WG [\%], $\rho_{W G}$ the WG density $\left[\mathrm{g} / \mathrm{m}^{3}\right], V_{W G}$ the volume of WG $\left[\mathrm{m}^{3}\right], m_{W G}$ the mass of WG $[\mathrm{g}]$. The particle coating was applied by pre-soaking the oven dried BA with the prepared WG solution with an L/S of 1 . After $24 \mathrm{~h}$, the BA was drained for $5 \mathrm{~min}$ by using a $500 \mu \mathrm{m}$ sieve, in order to remove the excess solution. Thereafter, coated BA was oven dried for $24 \mathrm{~h}$ at $70{ }^{\circ} \mathrm{C}$, and then applied in mortars as sand replacement.

\subsection{Environmental impact}

The environmental impact of the BA fraction (granular or unshaped material) is evaluated according to the EN 12457-2 (One stage batch leaching test) (Holm and Hansen, 2003; Florea, accepted for publication) by using a dynamic shaker (ES-SM-30 Edmund Buhler $\mathrm{GmbH}$ ) in ambient conditions (L/S 10, $250 \mathrm{rpm}$, $24 \mathrm{~h}$ ). On the other hand, the leaching assessment of the final products are tested as shaped material in the form of mortar prisms was addressed by using a reduced testing protocol for monolithic cement including MSWI products (van der Sloot et al., 1994), based on the standard tank leaching test for monolithic material is described in NEN 7345 (NEN 7345, 1995). The concise version used in this study reduces the testing time from 64 to 16 days, analysing the leachates after $2,8,24,48,72,102,168,384 \mathrm{~h}$ (16 days) and monitoring the $\mathrm{pH}$ for every time step. Previous studies have shown the comparability of this test with the official tank test (Kosson and van der Sloot, 1997; Lewin, 1996; Van Der Sloot, 1996; van der Sloot et al., 1996). The pH of the leachates of the tank test was measured by using VOLTCRAFT (PH-100ATC). The suspensions were filtered with $0.017-0.030 \mathrm{~mm}$ membrane filters and part of the solution was taken for chlorides and sulphates quantification by ion chromatography (Thermoscientific Dionex ICS-1100). The analysis of the heavy metals was performed after acidifying the samples with $0.2 \% \mathrm{HNO}_{3}$ by using inductively coupled plasma atomic emission spectrometry (ICP-OES) according to NE 6966 (NEN-EN 6966, 2005). The legislation limit for the leaching of contaminants for shaped material are set by the Dutch Soil Quality Decree (SQD), where sulphate, chlorides and heavy metals are regulated (“Soil Quality Decree", 2015).

\section{Results}

\subsection{Characterization of the materials}

The MSWI BA particles are chemically and physically tested. A comparison between BA and standard sand with the same particle fraction is provided in Table 1. The used BA presents $3.23 \mathrm{wt} . \%$ TOC, compared to the $0 \%$ of sand, due to the heterogeneity of the household waste collected for incineration, often containing residual organic matter (Qiao et al., 2008). Although having a similar specific gravity, BA presents a higher surface area and pore volume compared to sand, resulting in a lower bulk density and a higher water absorption (20 wt.\%). BA shows an irregular morphology of the particles characterized by sharp edges, a rough surface and an open structure (Fig. 1b)). Despite the coarser particle size distribution of BA compared to sand (Fig. 1a)), smaller residues covering the BA surface are also visible in Fig. 1b). This so called "fragile zone" is a layer of poorly-bonded ultrafine incineration residues (below $200 \mu \mathrm{m}$ ), which can include metals, organics and calcite particles (Saffarzadeh et al., 2011; Inkaew et al., 2014). The formation of this layer takes place after the quenching process, during weathering. The consolidation of quenching products around bigger melted particles occurs via the formation of capillary bridges and the hardening of newly formed phases (Inkaew et al., 2016). Due to these features, according to some studies (Saffarzadeh et al., 2011) this layer contributes to the porosity, and hence water adsorption, of the BA.

Chemically, BA shows differences from the standard composition of sand $\left(98 \% \mathrm{SiO}_{2}\right)$, as it includes various elements such as calcium, iron, and alumina, as well as alkalis (Table 2). Due to the presence of soluble phases, especially on the surface of the BA particles, the leachate of stored (landfilled) BA usually ranges between pH 8-11 (Johnson et al., 1995). As reported in literature also in this case, in mortars manufacture conditions ( $\mathrm{L} / \mathrm{S} 2$ ) the $\mathrm{pH}$ increases up to 10.1 , within $24 \mathrm{~h}$ (Fig. 2a)). This phenomenon is related to the concentrations of highly soluble alkali metal hydroxides or salts ( $\mathrm{Na}, \mathrm{K}, \mathrm{Mg}$, and $\mathrm{Ca}$ ) released when BA is in water (Fig. 2b)). The different concentrations of those alkali metal depend on their content in the BA, and on the solubility of the phases, where those elements are incorporated.

\begin{tabular}{|c|c|c|c|c|c|c|}
\hline & Bulk density, $\mathrm{g} / \mathrm{cm}^{3}$ & Specific gravity, $\mathrm{g} / \mathrm{cm}^{3}$ & BET surface area, $\mathrm{m}^{2} / \mathrm{g}$ & Total pores volume $<125 \mathrm{~nm}, \mathrm{~cm}^{3} / \mathrm{g}$ & Water Absorption, wt.\% & TOC $\left(550^{\circ} \mathrm{C}\right)$, wt. $\%$ \\
\hline BA & 1.0 & 2.68 & 4.247 & 0.0149 & 20.4 & 3.23 \\
\hline Sand & 1.5 & 2.65 & 0.848 & 0.0017 & 1.0 & - \\
\hline
\end{tabular}

Environmentally, the uncoated BA selected is not in compliance with the Dutch Soil Quality Decree (SQD) ("Soil Quality Decree", 2015) as granular material (Table 3). The main elements

Table 1

Physical properties of the reference sand and bottom ash applied in the study. 


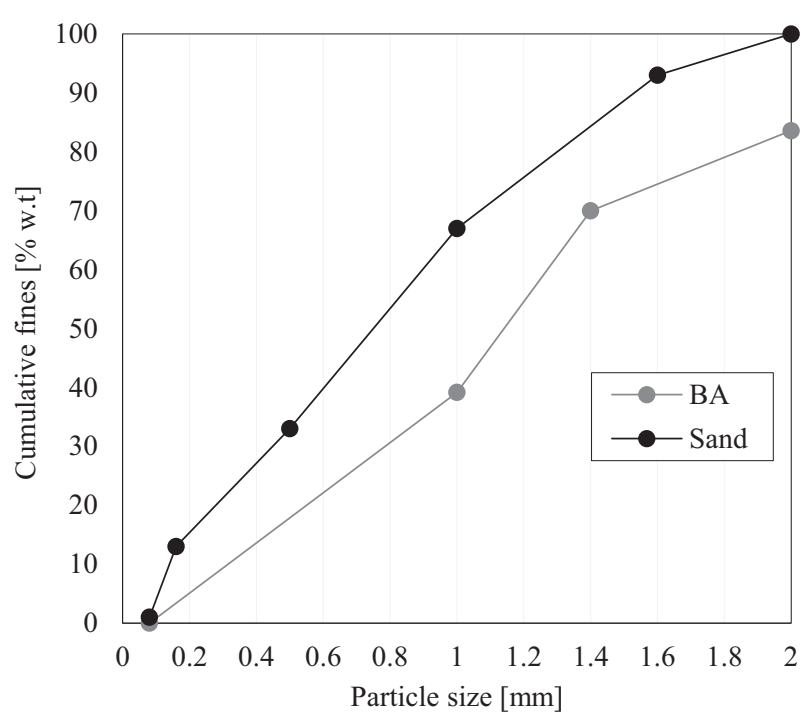

Fig. 1. (a) Particle size distribution of the BA and the reference fine sand aggregates, and (b) overview of BA particles before the application of the coating.

Table 2

Oxides composition of the materials applied in the study.

\begin{tabular}{|c|c|c|}
\hline Compound & $\begin{array}{l}\text { BA } \\
\text { wt.\% }\end{array}$ & $\begin{array}{l}\text { CEM } 52.5 \text { I R } \\
\text { wt.\% }\end{array}$ \\
\hline $\mathrm{Na}_{2} \mathrm{O}$ & 3.35 & - \\
\hline $\mathrm{MgO}$ & 2.22 & 1.80 \\
\hline $\mathrm{Al}_{2} \mathrm{O}_{3}$ & 7.32 & 3.93 \\
\hline $\mathrm{SiO}_{2}$ & 38.20 & 19.31 \\
\hline $\mathrm{P}_{2} \mathrm{O}_{5}$ & 1.37 & 0.8 \\
\hline $\mathrm{SO}_{3}$ & 2.25 & 3.69 \\
\hline $\mathrm{K}_{2} \mathrm{O}$ & 1.24 & 0.64 \\
\hline $\mathrm{CaO}$ & 19.47 & 64.02 \\
\hline $\mathrm{TiO}_{2}$ & 1.25 & - \\
\hline $\mathrm{Fe}_{2} \mathrm{O}_{3}$ & 10.21 & 3.25 \\
\hline $\mathrm{CuO}$ & 0.78 & - \\
\hline $\mathrm{Cl}$ & 0.98 & 0.02 \\
\hline Other Oxides & 2.63 & - \\
\hline LOI & 9.7 & - \\
\hline
\end{tabular}

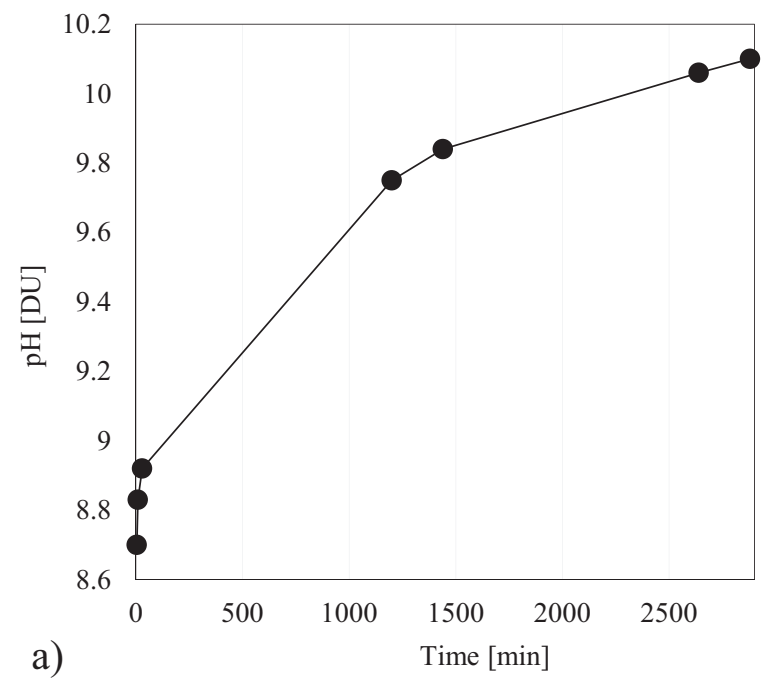

Table 3

One batch leaching test of the BA (NEN 12457-2) and the SQD legislation, performed by column test for granular materials. Values in bold are above the threshold.

\begin{tabular}{lll}
\hline & SQD Unshaped material, $\mathrm{mg} / \mathrm{kg}$ & $\mathrm{BA}, \mathrm{mg} / \mathrm{kg}$ \\
\hline $\mathrm{Cl}^{-}$ & 616 & $\mathbf{3 8 3 0}$ \\
$\mathrm{SO}_{4}^{2-}$ & 1730 & $\mathbf{9 5 9 0}$ \\
$\mathrm{Sb}$ & 0.32 & $\mathbf{1 . 7}$ \\
$\mathrm{As}$ & 0.9 & $<0.3$ \\
$\mathrm{Ba}$ & 22 & 0.6 \\
$\mathrm{Cd}$ & 0.04 & $<0.02$ \\
$\mathrm{Cr}$ & 0.63 & 0.5 \\
$\mathrm{Co}$ & 0.54 & 0.02 \\
$\mathrm{Cu}$ & 0.9 & $\mathbf{6 . 4 7}$ \\
$\mathrm{Pb}$ & 2.3 & 0.6 \\
$\mathrm{Mo}$ & 1 & 0.97 \\
$\mathrm{Ni}$ & 0.44 & 0.2 \\
$\mathrm{Se}$ & 0.15 & $<0.02$ \\
$\mathrm{Sn}$ & 0.4 & $<0.1$ \\
$\mathrm{~V}$ & 1.8 & $<0.1$ \\
$\mathrm{Zn}$ & 4.5 & 2.19 \\
\hline
\end{tabular}

overcoming the thresholds for leaching are chloride and sulphate, (6 and 15 times higher than the SQD limit, respectively) as well as antimony and copper (5 and 7 times higher than the SQD limit, respectively).

\subsection{Influence of the waterglass coating in the BA particle morphology}

The amount of waterglass applied to achieve each theoretical thickness $(10,15,20 \mathrm{~nm})$ is shown in Table 4(a), as rate of the BA dried mass. After the application of the coating treatment, the modification of the BA structure is analysed for all the samples with different layer thicknesses. For all cases, the particles appear smoother and more homogeneous due to the adsorption of the WG on their surface (Fig. 3(a)), which shows a chemical composition of $19.10 \% \mathrm{SiO}_{2}$ and $10.47 \% \mathrm{NaO}_{2}$, based on the atomic weight (EDX analysis). Neither the fragile zone nor the major pores are visible in the coated particle. A graphical representation of this process is provided in Fig. 3(b).

The BET surface area and total pore volume of BA as a function of the different theoretical coating thicknesses are shown in Fig. 4 (a). Compared to the uncoated BA $(0 \mathrm{~nm})$, the BET surface area and pore volume decrease with the increase of the coating thickness. The improvement provided by the coating is maximized for the

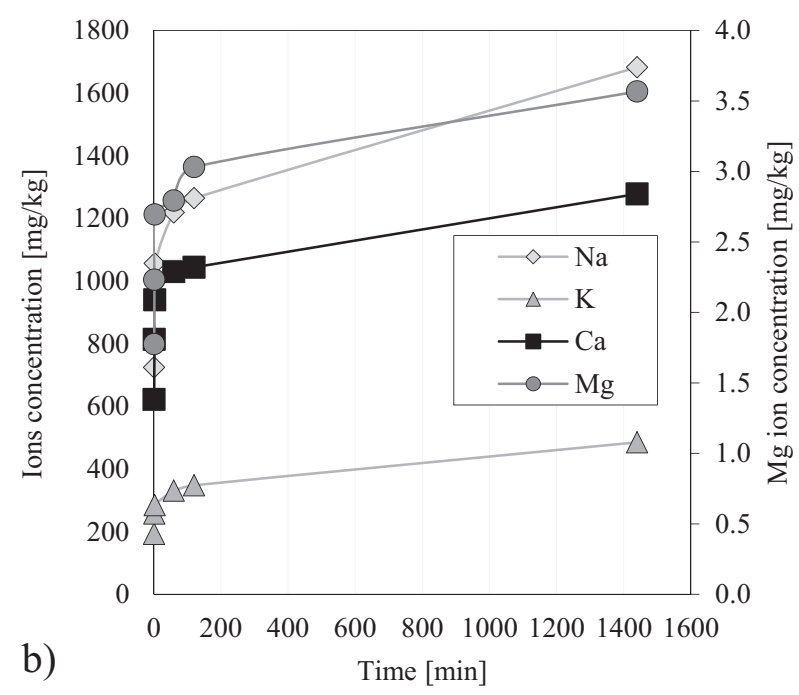

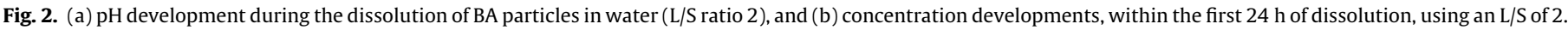


Table 4

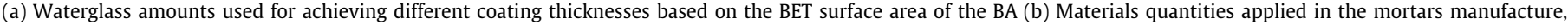
based on the total mass of the mortars.

\begin{tabular}{|c|c|c|c|c|}
\hline \multicolumn{5}{|c|}{ Section (a) - WG coating amounts and computed thicknesses based on BET } \\
\hline & Initial BET surface area BA, $\mathrm{m}^{2} / \mathrm{g}$ & WG solution $\left(\mathrm{Na}_{2} \mathrm{SiO}_{3}+\mathrm{H}_{2} \mathrm{O}\right)$, \% BA wt. & WG oven dried $\left(\mathrm{Na}_{2} \mathrm{SiO}_{3}\right)$, \% BA wt. & Coating Thickness, nm \\
\hline BA10 & 4.25 & 33.74 & 12.17 & 10 \\
\hline BA15 & 4.25 & 50.61 & 18.26 & 15 \\
\hline BA20 & 4.25 & 67.49 & 24.35 & 20 \\
\hline \multicolumn{5}{|c|}{ Section (b) - Materials rates for mortars including $20 \mathrm{~nm}$ coated $\mathrm{BA}^{\mathrm{a}}$} \\
\hline & BA, wt.\% & WG oven dried, wt.\% & Sand, wt.\% & PC, wt.\% \\
\hline BA20_25 & 6.13 & 1.50 & 60.53 & 22.22 \\
\hline BA20_50 & 11.15 & 2.70 & 55.51 & 22.22 \\
\hline BA20_75 & 16.73 & 4.10 & 49.93 & 22.22 \\
\hline BA20_100 & 22.31 & 5.40 & 44.35 & 22.22 \\
\hline
\end{tabular}

${ }^{a}$ Water rate is set at $11.11 \%$ wt. for every sample.

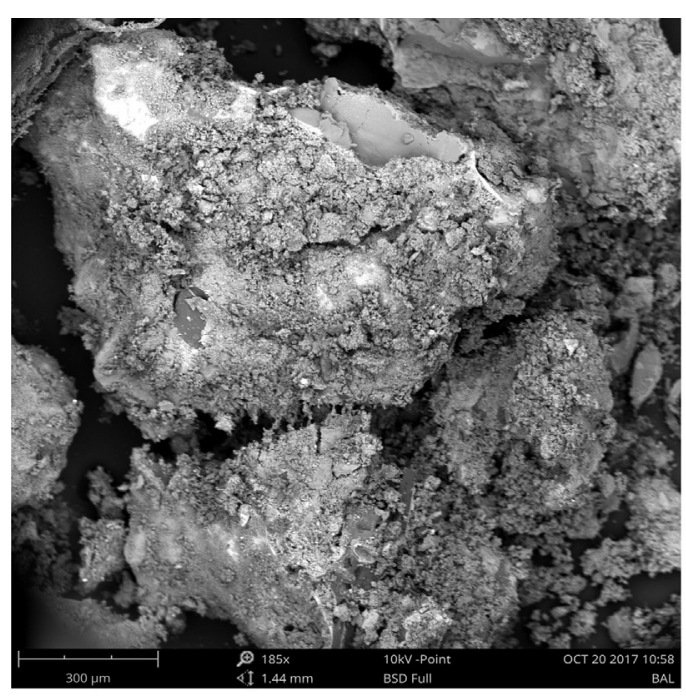

a)

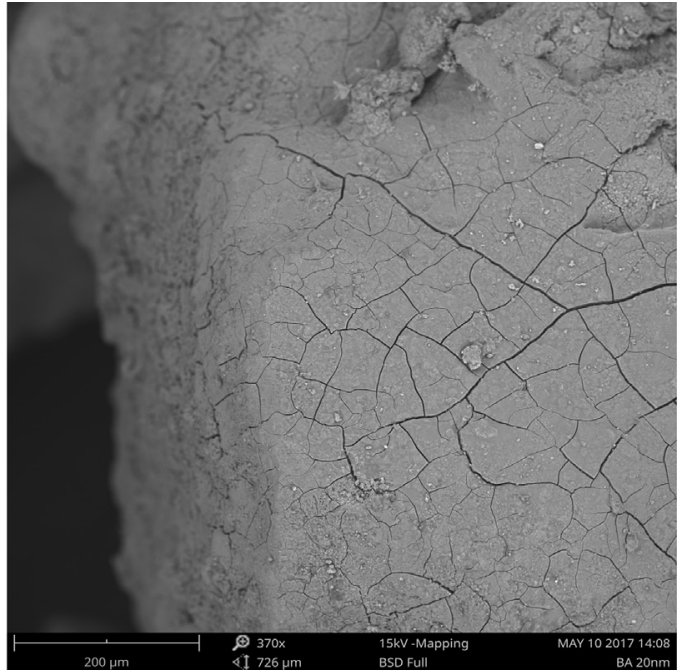

b)

Fig. 3. SEM picture of (a) uncoated BA particle and (b) the sodium silicate coating layer on the BA surface after the impregnation treatment.

$20 \mathrm{~nm}$ thickness (WG content corresponds to $24 \mathrm{wt} . \%$ of the oven dry BA mass, Table 4), where WG fills the pores reducing the pore volume by $56 \%$ and the BET surface area by $60 \%$. For pore sizes lower than $50 \mathrm{~nm}$, an increasing difference with the coating thickness in the cumulative pore area is observed (Fig. 4(b)). Compared to standard sand, the coated BA presents a higher cumulative pore area independently on the coating thickness (Fig. 4(b)). As the closest surface area is achieved in presence of $20 \mathrm{~nm}$ coating, all further analysis will be performed considering different sand replacements based on the theoretical thickness. For the optimal thickness chosen, the amounts of materials used for the mortars manufacture are presented in Table 4(b).

\subsection{Influence of the waterglass coating on the mechanical properties of the mortars including MSWI BA}

Optimized the coating thickness (BA20), the rheological properties of the cement paste are evaluated. Fig. 5(a) illustrates the mini spread flow for sand replacement of 25\%, 50\%, 75\% and $100 \mathrm{vol} . \%$, for coated and uncoated particles. The spread flow is highly reduced (up to 36\%) for 50\% replacements of uncoated BA (BA_50). This phenomenon is caused by the high water adsorption of the BA aggregates, which results in higher viscosities for the pastes. By having a low spread flow, the application as normal concrete is not possible for BA_50, BA_75 and BA_100 without BA treatment. Once WG coating is applied the water adsorption of the $B A$ is significantly reduced, with a difference of $15 \%$ (BA20_100) compared to the reference PC.

The mechanical performances of the mortars at 28 days are represented in Fig. 5(b) and (c) as function of the uncoated and coated $B A$ replacement (BA and BA20, respectively). In absence of coated $\mathrm{BA}$, samples show always lower performances compared to PC, due to the BA porous structure (Bogas and Gomes, 2013; Chen et al., 2013; Gao et al., 2017b). The BA_75 and BA_100 display higher mechanical performances compared to BA_25, BA_50, BA20_75 and BA20_100, due to the high water absorption of the uncoated BA (Table 1). This phenomenon is measured also during the workability test (Fig. 5(a)), where the spread flow diameters of BA_75 and BA_100 is limited to $9.5 \mathrm{~cm}$ preventing their application as secondary building material. However, by absorbing the water available for reaction, BA_75 and BA_100 result in a lower effective $\mathrm{L} / \mathrm{S}$ ratio and hence a denser and stronger matrix.

\subsubsection{Flexural strength}

With a 50\% replacement, high mechanical strength is achieved. Compared to the reference $(6.8 \mathrm{MPa})$, the $50 \%$ replacement of coated BA results in a similar flexural strength (BA20_50, $6.5 \mathrm{MPa}$ ) overcoming the strength of the uncoated sample by $22 \%$ (Fig. 5(b)). In spite of the use of weak aggregates, the high flexural values of BA20_50 can be explained by the presence of the WG 


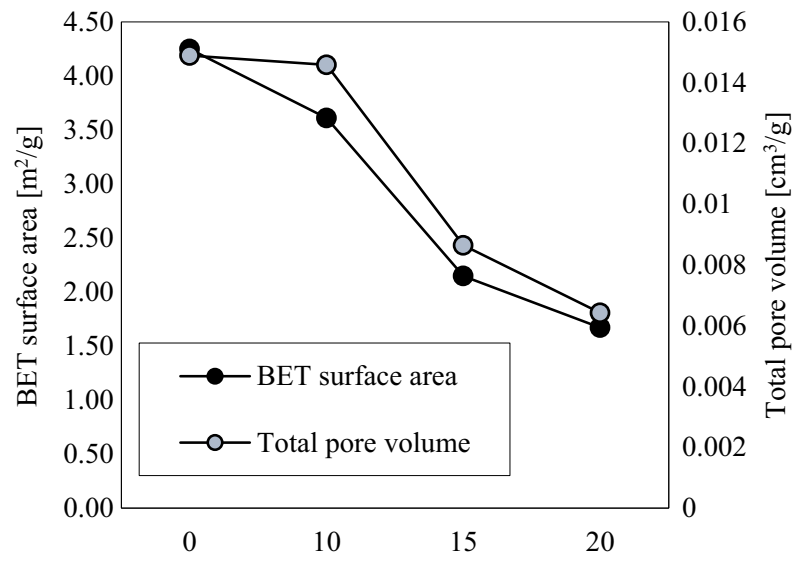

a) Theoretical coating thickness [nm]

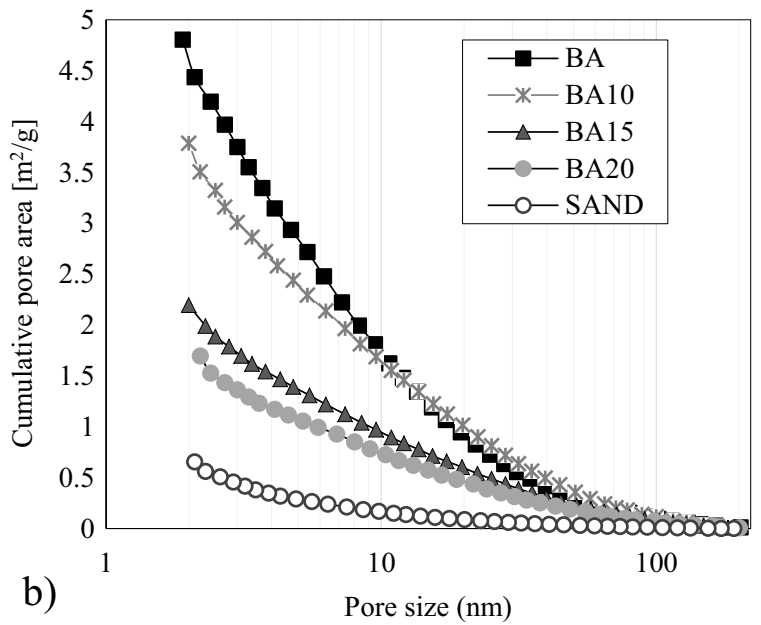

Pore size (nm)

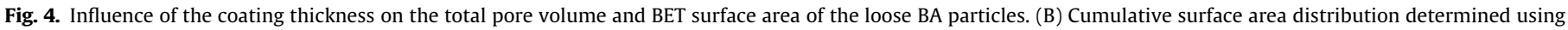
the BJH method, as function of the pore average size of loose BA particles for different coating thickness. The coating thickness 0 corresponds to the uncoated BA.
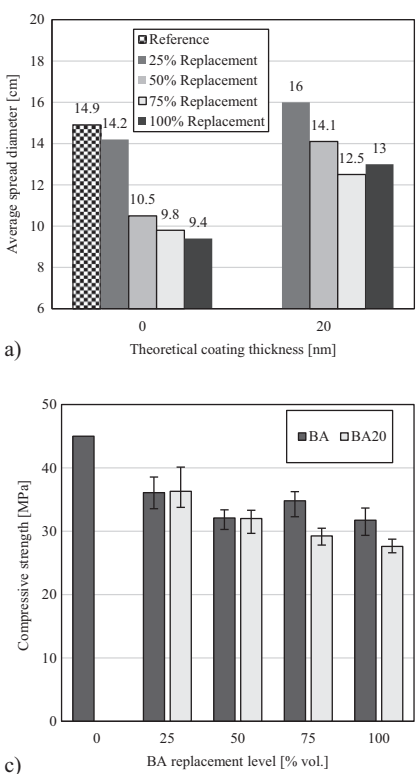

Fig. 5. (a) Mini spread flow of the coated and uncoated pastes for different replacement levels. The value 0 on the $x$ axis identifies the uncoated samples. The reference sample represents the spread flow of PC with standard sand. (b) Flexural strength and (c) compressive strength of mortars including between $25 \%$ and $100 \%$ BA as fine aggregates. The bar in correspondence of $0 \%$ represents the reference performance. The coating thickness has been calculated based on the initial BA BET surface area. d) Porosity and bulk density of the mortars, as function of the replacement level.

coating. The flexural strength mainly depends on the performance of the interfacial transition zone (ITZ) between matrix and aggregates (Chandra and Berntsson, 2002; Newman and Choo, 2003). In the presence of standard aggregates, the ITZ consists principally of calcium hydroxide $(\mathrm{CH})$ and ettringite (AFt) anchored directly on the aggregates (Hu and Stroeven, 2004). The precipitation of those reaction products is related to the higher mobility of ions such as $\mathrm{Ca}^{2+}, \mathrm{Al}^{3+}$ of $\mathrm{SO}_{4}^{2-}$ on the ITZ due to its higher water to binder ratio (w/b) compared to the paste (Hu and Stroeven, 2004; Scrivener et al., 2004). The presence of $\mathrm{CH}$ and AFt phases creates weaker areas in the matrix, where the failure is more likely to occur. The presence of pozzolanic material within the ITZ makes silicates available for reaction and it favours the formation of $\mathrm{C}-\mathrm{S}-\mathrm{H}$ gel
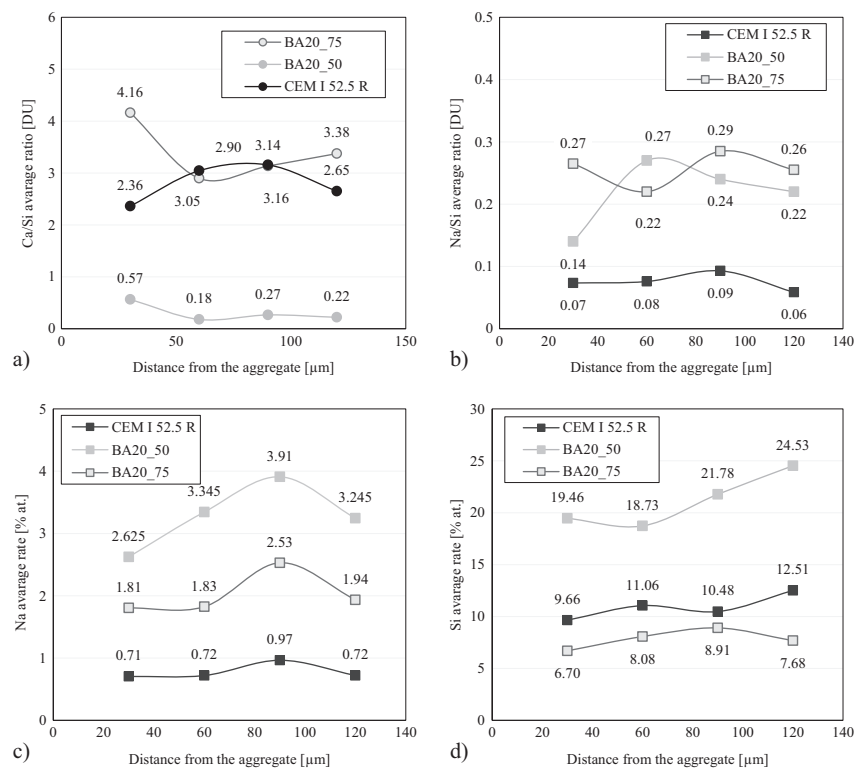

Fig. 6. (a) Effective atomic $\mathrm{Ca} / \mathrm{Si}$ ratio (b) Effective atomic $\mathrm{Na} / \mathrm{Si}$ ratio and (c) Effective Na rate (d) Effective Si rate of the samples CEM I 52.5 R, BA20_50 and BA20_75 as function of the distance from the aggregate, measured by EDX.

rather than Aft and $\mathrm{CH}$ phases (Hu and Stroeven, 2004; Scrivener et al., 2004), leading to improved mechanical performances.

For the evaluation of this phenomenon, the effective trends of the $\mathrm{Ca} / \mathrm{Si}$ atomic ratio, measured by EDX, are shown in Fig. 6(a), as function of the distance from the aggregates. The $\mathrm{Ca} / \mathrm{Si}$ ratio of hydrated PC ranges between 2.5 and 2.7, due to the presence of C-S-H phases $(\mathrm{Ca} / \mathrm{Si} \approx 1.75$, (Rossen et al., 2015)) and reaction products such as $\mathrm{AFt}, \mathrm{AFm}$ and $\mathrm{CH}$, which increase the overall calcium content, and, thus, the Ca/Si ratio. For BA20_50, the WG coating dissolves quickly providing silicates and lowering the $\mathrm{Ca} / \mathrm{Si}$ ratios compared to the reference (Fig. 6(a)). Therefore, the presence of available silicates stimulates the formation of hydration products (i.e. C-S-H) with higher silica content, explaining in greater mechanical performances (Kunther et al., 2017). Although not all the silicates participate to the gel formation, the presence of WG coating on BA seems beneficial for the reinforcement of the ITZ within $50 \%$ replacement. 
Over $50 \%$ replacements, the presence of the coating results in a decrease of the flexural strength compared to the reference (35\% and $44 \%$, for BA20_75 and BA20_100 respectively). Analysing Fig. 6(a), the $\mathrm{Ca} / \mathrm{Si}$ ratio in proximity of the aggregates for BA20_75 is higher than BA20_50. Because the Ca/Si ratio is similar to the PC one, it is likely that the WG layer is not properly dissolved, limiting the availability of silicates in BA20_75 (high Ca/ $\mathrm{Si}$ ). In Fig. 6(b) the $\mathrm{Na} / \mathrm{Si}$ ratio displays similar trends for BA20_50, BA20_75 and the pure WG ( $\mathrm{Na} / \mathrm{Si}$ ratio 0.31$)$, whereas PC is characterized by a lower alkali ratio. Since the increasing amount of $\mathrm{Na}^{2+}$ is mainly related to the presence of WG, the correspondences of the $\mathrm{Na} / \mathrm{Si}$ ratios indicate that a similar dissolution behaviour of the coating is taking place. However, in spite of the lower WG content the chemical compositions of the reaction products (Fig. 6(c) and (d)) show higher rates of both $\mathrm{Na}$ and $\mathrm{Si}$ in BA20_50 compared to PC and BA20_75. Therefore, in sample BA20_75 the WG coating is not dissolving as much as BA20_50 providing lower concentration of $\mathrm{Na}$ and $\mathrm{Si}$ ions and resulting in a higher $\mathrm{Ca} / \mathrm{Si}$ ratio, as detected in Fig. 6(a). The high content of WG in cementitious systems is known to be able to affect the PC hydration, causing fast setting in early stages of reaction (Brykov et al., 2002; Caijun et al., 2006; Inkaew et al., 2016). The fast setting is mainly related to the presence of alkali metals, which stimulates the dissolution of PC catalysing the hydration products (e.g. C-S-H gel), due to the presence of additional silicates (Inkaew et al., 2016). In BA20_75 the formation of those reaction products limits the further dissolution of the WG due to the fast hardening of the paste, resulting in mortars with low strength. This phenomenon is further confirmed by the EDX analysis in Fig. 7(a), where the WG coating is still observable around the particles after 28 days reaction. In this case, the weakest area of the system becomes the WG layer, where cracks and failure are observed.

\subsubsection{Compressive strength}

The compressive strength of the mortars is not improved by the presence of the WG independently of the replacement level: in the case of $25-50 \%$ replacement, the mechanical performances of coated and uncoated BA mortars are the same (Fig. 5(c)). Knowing that the ITZ is improved in presence of the coating, the development of a comparable compressive strength suggests that failure is not localized in this area. In presence of porous aggregates many studies have observed the failure mechanism localized in the aggregate itself, pointing out them as the weakest part of the system (Bogas and Gomes, 2013; Gerritse, 1981). This phenomenon is also observed in BA20_50 samples (Fig. 7(b)). The presence of cracks developing through the BA aggregate, instead of along the ITZ, supports the failure mechanism of lightweight concrete (LWC). Contrary to normal concrete, in LWC the stress distribution occurs mainly through the matrix, because of the lower stiffness of the porous aggregates compared to sand. Therefore, being the ITZ stronger in presence of the coating, the failure path (crack) travels through the BA aggregate, limiting the mechanical strength of the mortars (Lo and Cui, 2004). For replacement higher than 50 vol.\%, a lower compressive strength is measured in presence of the coating (Fig. 5(c)), due to the failure localized in the unreacted WG coating (Fig. 7(a)), which means that the weakest part now is the coating.

Finally, the density of the mortars is also affected by the BA replacement, resulting in $1700 \mathrm{~kg} / \mathrm{m}^{3}$ for $100 \mathrm{vol} . \%$ replacement (Fig. 5(d)). Because of the low density generated by the combination of normal-weight aggregates and porous by-products (BA), BA20_75 and BA20_100 can be classified as semi-lightweight product, as defined in ASTM C 330 (ASTMC 330 - Lightweight Aggregates for Structural Concrete, 2000). Therefore, the presence of WG coating allows the successful manufacture of a lightweight product, enhancing the rheological behaviour and leading to a proper compaction during casting.

\subsection{Influence of the coating on the environmental impact of the $B A$}

The environmental impact as shaped material is evaluated by a reduced tank test. The evaluation of the leachates shows a $\mathrm{pH}$ trend ranging between 11.7 and 12 , independently on the replacement level and on the coating thickness. This ensures a correct comparison among the leachates due to the similar testing conditions.

The leaching behaviours of the coated and uncoated samples are described in Fig. 8. Independently on the replacement level, all the samples completely fulfil the legislation threshold for shaped material for all the contaminants, showing the beneficial immobilization provided by the hydrated PC matrix (Appendix B). In the samples without coating, the leaching trends of chlorides, barium, copper and zinc are increasing with the content of MSWI

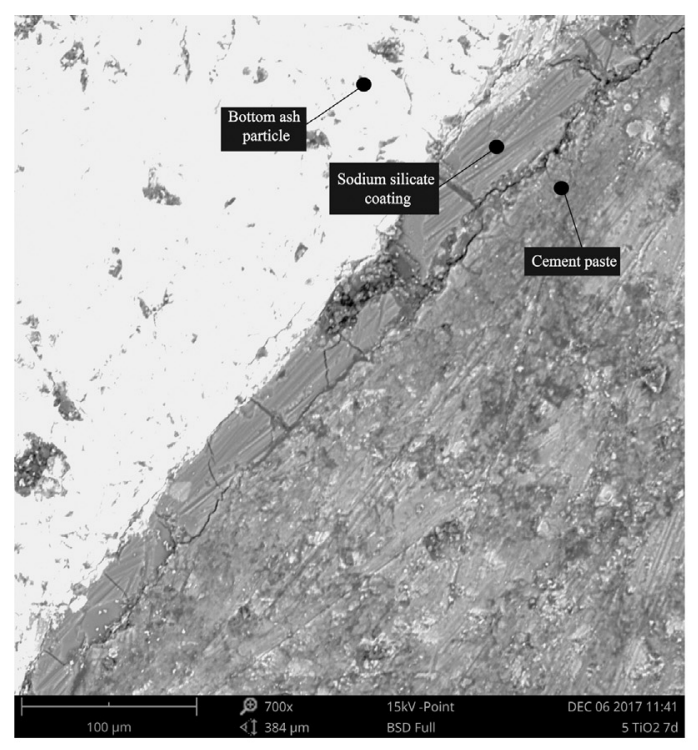

(a)

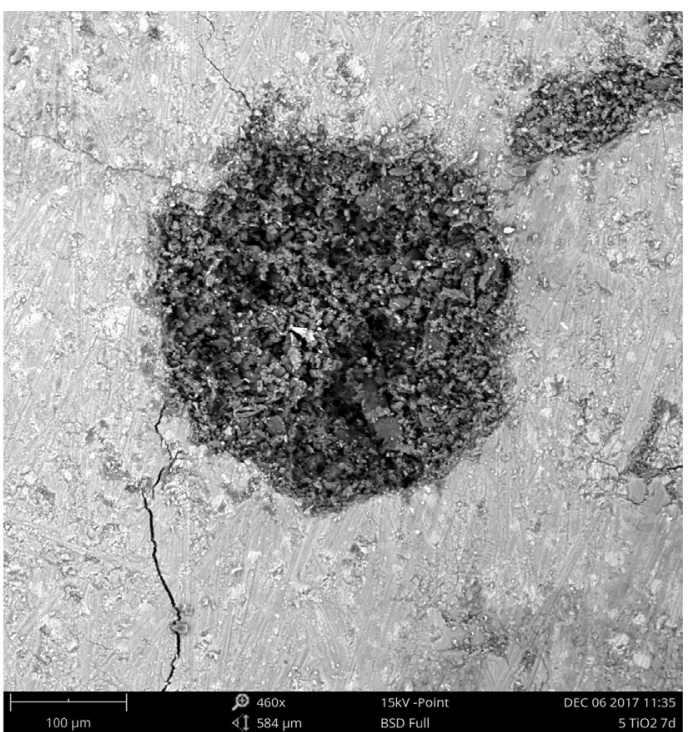

(b)

Fig. 7. (a) SEM overview of the undissolved WG coating after 28 days curing in BA20_75 and of (b) the failure of BA aggregates in the sample BA20_50. 


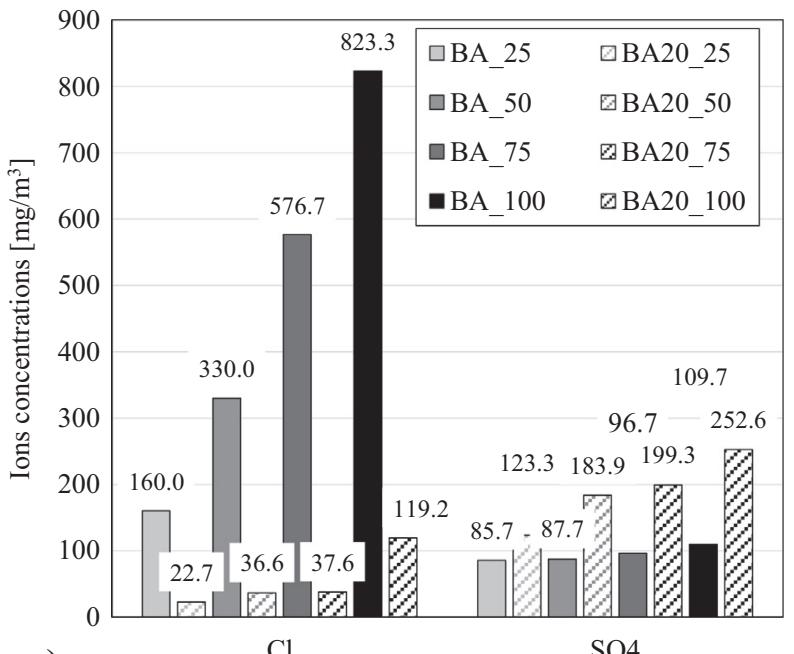

a)

$\mathrm{Cl}$

$\mathrm{SO} 4$

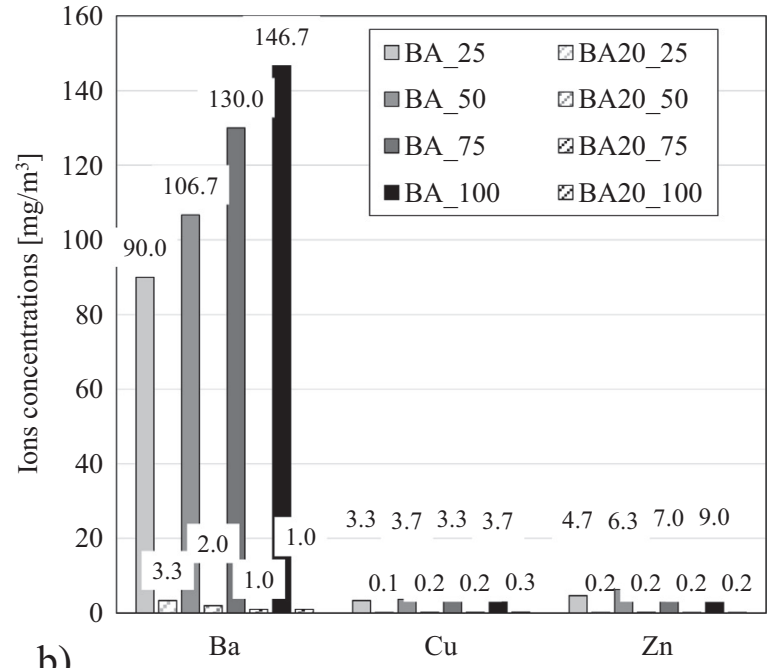

b)

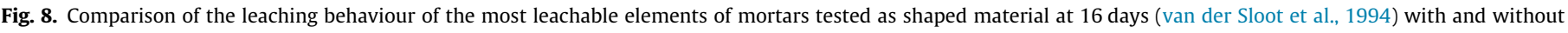
coating, measured by IC and ICP/OES. An integral version of the data, including the limits imposed by the soil quality decree, is available in the appendix B.

$\mathrm{BA}$, due to the rising contaminants amount. In the presence of the coating, the leaching of chlorides, barium, copper and zinc are reduced by $88,98,94$ and $97 \%$, respectively. The lower leaching is due to the presence of a denser matrix around the BA aggregates, limiting the dissolution and dispersion of the contaminants located internally. Moreover, the addition of WG reduces the $\mathrm{Ca} / \mathrm{Si}$ ratio of the reaction products (Fig. 6(a)), favouring the immobilization of the contaminants. This phenomenon is in agreement with the findings of Giergiczny and Król (2008) and Nocun-Wczelik and Malolepszy (1997), which showed that the presence of a gel with a low $\mathrm{Ca} / \mathrm{Si}$ ratio is beneficial for the immobilization of heavy metals. On the other hand, a reverse trend is observed for sulphates, whose leaching is increased in presence of the coating. This could be due to the formation of highly soluble phases incorporating $\mathrm{SO}_{4}^{2-}$ (e.g. $\mathrm{Na}_{2} \mathrm{SO}_{4}$ ) during the pre-treatment with WG as was proposed by Alam et al. (2017). However, no proof of the presence of sulphate phases was obtained, since the concentration of sulphates is below the detection limit of XRD analysis.

\section{Conclusions}

This study evaluates the influence of waterglass impregnation treatment on the performances of BA as sand replacement in mortars. Based on the analysis performed the following conclusions can be drawn:

- The impregnation treatment based on sodium silicate creates a uniform coating on the aggregates smoothing their surface and reducing porosity. The BET surface area and the total pore volume of the BA aggregates is reduced by $56 \%$ and $60 \%$, respectively when WG to form a $20 \mathrm{~nm}$ coating is employed.

- The presence of the coating limits the water adsorption of the MSWI BA enhancing the paste spread flow by $38 \%$ when $100 \%$ sand is replaced.

- Using $20 \mathrm{~nm}$ coating, optimal mechanical performances in presence of coated BA are observed for $50 \%$ replacement, having a flexural strength of $6.5 \mathrm{MPa}$, which is the same as the reference. For this replacement level, the compressive strength is only reduced by $28 \%$ ( $32 \mathrm{MPa}$ ) compared to the reference material (45 MPa).

- Lightweight mortars with densities below $1800 \mathrm{~kg} / \mathrm{m}^{3}$ can be successfully produced with sand replacement levels above 50 vol.\% The minimal strength requirement is also fulfilled, with values $58 \%$ above the requirement ( $17 \mathrm{MPa}$ ).

- Independent of the replacement level, the leaching values comply with the Dutch legislation thresholds for shaped materials. In presence of the coating, the leaching of barium, copper, zinc and chlorides is reduced by $98,94,97$ and $88 \%$, respectively.

- Overall, the impregnation treatment based on sodium silicate is beneficial for the application of MSWI BA as fine aggregates. The enhancement of the mechanical and leaching behaviour of the final product is mainly linked to the reduction of the particles porosity and surface area. As a consequence, the mortar paste shows a rheological behaviour comparable to the reference despite the high BA rate. Moreover, the high content of silica leads to the modification of the ITZ chemical composition, enhancing mechanical behaviour and limiting the release of contaminants.

\section{Appendix}

Appendix A:. Graphical representation of the methodology applied in the study for the determination of the effective elements ratio by EDX

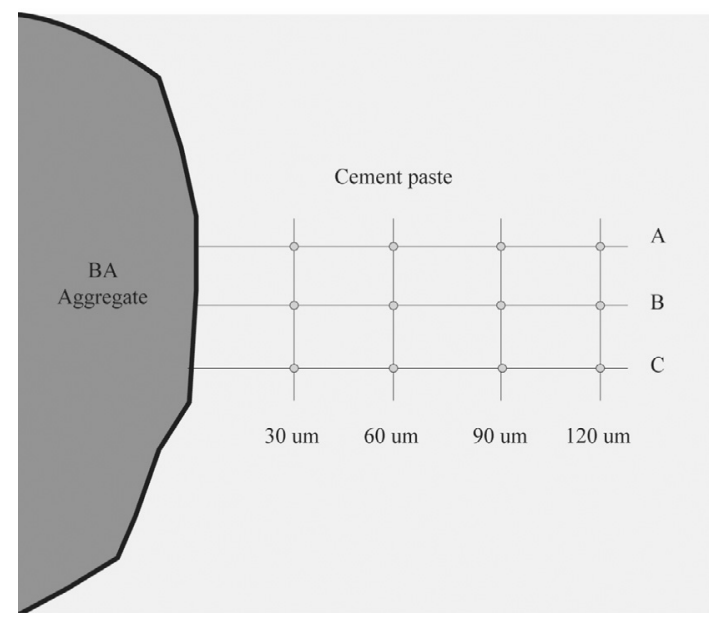




\begin{tabular}{|c|c|c|c|c|c|c|c|c|c|}
\hline & $\begin{array}{l}\text { SQD Shaped } \\
\text { material, } \mathrm{mg} / \mathrm{m}^{2}\end{array}$ & $\begin{array}{l}\text { BA_25, } \\
\mathrm{mg} / \mathrm{m}^{2}\end{array}$ & $\begin{array}{l}\text { BA20_25, } \\
\mathrm{mg} / \mathrm{m}^{2}\end{array}$ & $\begin{array}{l}\text { BA_50, } \\
\mathrm{mg} / \mathrm{m}^{2}\end{array}$ & $\begin{array}{l}\text { BA20_50, } \\
\mathrm{mg} / \mathrm{m}^{2}\end{array}$ & $\begin{array}{l}\text { BA_75, } \\
\mathrm{mg} / \mathrm{m}^{2}\end{array}$ & $\begin{array}{l}\text { BA20_75, } \\
\mathrm{mg} / \mathrm{m}^{2}\end{array}$ & $\begin{array}{l}\text { BA_100, } \\
\mathrm{mg} / \mathrm{m}^{2}\end{array}$ & $\begin{array}{l}\text { BA20_100, } \\
\mathrm{mg} / \mathrm{m}^{2}\end{array}$ \\
\hline $\mathrm{Cl}^{-}$ & 110,000 & 160.0 & 232.8 & 330.0 & 36.6 & 576.7 & 37.6 & 823.3 & 119.2 \\
\hline $\mathrm{SO}_{4}^{2-}$ & 165,000 & 85.7 & 123.4 & 87.7 & 183.6 & 96.7 & 199.3 & 146.7 & 252.6 \\
\hline $\mathrm{Sb}$ & 8.7 & $<0.3$ & $<0.3$ & $<0.3$ & $<0.3$ & $<0.3$ & $<0.3$ & $<0.3$ & $<0.3$ \\
\hline As & 260 & $<1.0$ & $<1.0$ & $<1.0$ & $<1.0$ & $<1.0$ & $<1.0$ & $<1.0$ & $<1.0$ \\
\hline $\mathrm{Ba}$ & 1500 & 90.0 & 3.3 & 106.7 & 2.0 & 130.0 & 1.0 & 146.7 & 1.0 \\
\hline $\mathrm{Cd}$ & 3.8 & $<0.1$ & $<0.1$ & $<0.1$ & $<0.1$ & $<0.1$ & $<0.1$ & $<0.1$ & $<0.1$ \\
\hline $\mathrm{Cr}$ & 120 & $<0.7$ & $<0.7$ & $<0.7$ & $<0.7$ & $<0.7$ & $<0.7$ & $<0.7$ & $<0.7$ \\
\hline Co & 60 & $<0.1$ & $<0.1$ & $<0.1$ & $<0.1$ & $<0.1$ & $<0.1$ & $<0.1$ & $<0.1$ \\
\hline $\mathrm{Cu}$ & 98 & 3.3 & 0.1 & 3.7 & 0.2 & 3.3 & 0.2 & 3.7 & 0.3 \\
\hline $\mathrm{Pb}$ & 400 & $<0.3$ & $<0.3$ & $<0.3$ & $<0.3$ & $<0.3$ & $<0.3$ & $<0.3$ & $<0.3$ \\
\hline Mo & 144 & $<0.2$ & $<0.2$ & $<0.2$ & $<0.2$ & $<0.2$ & $<0.2$ & $<0.2$ & $<0.2$ \\
\hline $\mathrm{Ni}$ & 81 & $<0.2$ & $<0.2$ & $<0.2$ & $<0.2$ & $<0.2$ & $<0.2$ & $<0.2$ & $<0.2$ \\
\hline Se & 4.8 & $<0.7$ & $<0.7$ & $<0.7$ & $<0.7$ & $<0.7$ & $<0.7$ & $<0.7$ & $<0.7$ \\
\hline Sn & 50 & $<0.3$ & $<0.3$ & $<0.3$ & $<0.3$ & $<0.3$ & $<0.3$ & $<0.3$ & $<0.3$ \\
\hline V & 320 & $<0.3$ & $<0.3$ & $<0.3$ & $<0.3$ & $<0.3$ & $<0.3$ & $<0.3$ & $<0.3$ \\
\hline $\mathrm{Zn}$ & 800 & 4.7 & $<0.2$ & 6.3 & 0.2 & 7.0 & 0.2 & 9.0 & 0.2 \\
\hline
\end{tabular}

\section{References}

Alam, Q., Florea, M.V.A., Schollbach, K., Brouwers, H.J.H., 2017. A two-stage treatment for Municipal Solid Waste Incineration (MSWI) bottom ash to remove agglomerated fine particles and leachable contaminants. Waste Manag. 67, 181-192. https://doi.org/10.1016/j.wasman.2017.05.029.

ASTMC 330 - Lightweight Aggregates for Structural Concrete, 2000, Concrete $10.1520 / \mathrm{C} 0330$

Bogas, J.A., Gomes, A., 2013. Compressive behavior and failure modes of structural lightweight aggregate concrete - characterization and strength prediction. Mater. Des. 46, 832-841. https://doi.org/10.1016/j.matdes.2012.11.004.

Brykov, A.S., Danilov, V.V., Korneev, V.I., Larichkov, A.V., 2002. Effect of hydrated sodium silicates on cement paste hardening. Russ. J. Appl. Chem. 75, 15771579. https://doi.org/10.1023/A:1022251028590.

Caijun, S., Roy, D., Krivenko, P., 2006. Alkali-Activated Cements and Concretes. Taylor \& Ffrancis e-library.

Chandler, A.J., Eighmy, T.T., Hartlén, J., Hjelmar, O., Kosson, D.S., Sawell, S.E., Sloot, H A. van der, Vehlow, J., 1997. Bottom ash. In: Municipal Solid Waste Incinerator Residues, pp. 339-417, 10.1016/S0166-1116(97)80015-5.

Chandra, S., Berntsson, L., 2002. Lightweight Aggregate Concrete.

Chen, X., Wu, S., Zhou, J., 2013. Influence of porosity on compressive and tensile strength of cement mortar. Constr. Build. Mater. 40, 869-874. https://doi.org/ 10.1016/j.conbuildmat.2012.11.072.

Cui, S., Yu, S., Lin, B., Shen, X., Gu, D., 2015. Preparation of $\mathrm{SiO}_{2}$ aerogel from rice husk ash. RSC Adv. 5, 65818-65826. https://doi.org/10.1039/C5RA08886K.

Dodson, J.R., Cooper, E.C., Hunt, A.J., Matharu, A., Cole, J., Minihan, A., Clark, J.H., Macquarrie, D.J., 2013. Alkali silicates and structured mesoporous silicas from biomass power station wastes: the emergence of bio-MCMs. Green Chem. 15, 1203. https://doi.org/10.1039/c3gc40324f.

EN 1015-10, 2006. Mortar, Methods of test for mortar for masonry - Part 10 : Determination of dry bulk density of hardened.

EN 1015-3, 2007. Methods of test for mortar masonry - Part 3: Determination of consistence of fresh mortars (by flow table).

EN 196-1, 2005. Method for testing cement - Part 1: Determination of strength.

EN 933-2, 1996. Tests for geometrical properties of aggregates. Determination of particle size distribution. Test sieves, nominal size of apertures.

Florea, M.V.A., 2016. Environmental Interactions of Cement-Based Products. Int. Conf. Adv. Cem. Concr. Technol. Africa, Dar es Salaam, Tanzania.

Gao, X., Yu, Q.L., Lazaro, A., Brouwers, H.J.H., 2017a. Investigation on a green olivine nano-silica source based activator in alkali activated slag-fly ash blends: reaction kinetics, gel structure and carbon footprint. Cem. Concr. Res. 100, 129139. https://doi.org/10.1016/j.cemconres.2017.06.007.

Gao, X., Yuan, B., Yu, Q.L., Brouwers, H.J.H., 2017b. Characterization and application of municipal solid waste incineration (MSWI) bottom ash and waste granite powder in alkali activated slag. J. Clean. Prod. 164, 410-419. https://doi.org/ 10.1016/j.jclepro.2017.06.218.

Gerritse, A., 1981. Design considerations for reinforced lightweight concrete. Int. J. Cem. Compos. Light. Concr. 3, 57-69. https://doi.org/10.1016/0262-5075(81) 90031-2.

Ghouleh, Z., Shao, Y., 2018. Turning municipal solid waste incineration into a cleaner cement production. J. Clean. Prod. 195, 268-279. https://doi.org/ 10.1016/j.jclepro.2018.05.209.

Giergiczny, Z., Król, A., 2008. Immobilization of heavy metals (Pb, Cu, Cr, Zn, Cd, Mn) in the mineral additions containing concrete composites. J. Hazard. Mater. 160 247-255. https://doi.org/10.1016/j.jhazmat.2008.03.007.
Hendrix, Y., Alam, Q., Thijs, L., Lazaro, A., Brouwers, H.J.H., 2017. Green synthesis of water-glass from municipal solid waste incineration bottom ash. In: The 9th International Symposium on Cement and Concrete (ISCC 2017). Wuhan.

Holm, J., Hansen, J.B., 2003. CEN EN 12457 leaching test : Comparison of test results obtained by part 1 and 2 with test results obtained by part 3 Dorthe Lærke. Baun Jesper Holm Jette Bjerre Hansen Margareta Wahlström.

Hu, J., Stroeven, P., 2004. Properties of the Interfacial Transition Zone in Model Concrete, pp. 389-397.

Inkaew, K., Saffarzadeh, A., Shimaoka, T., 2016. Modeling the formation of the quench product in municipal solid waste incineration (MSWI) bottom ash. Waste Manag. 52, 159-168. https://doi.org/10.1016/j.wasman.2016.03.019.

Inkaew, K., Saffarzadeh, A., Shimaoka, T., 2014. Characterization of grate sifting deposition ash, unquenched bottom ash and water-quenched bottom ash from mass-burn moving grate waste to III_469-III_475 Energy Plant. J. Japan Soc. Civ. Eng. Ser. G Environmental Res. 70. https://doi.org/10.2208/jscejer.70.III_469.

Johnson, C.A., Brandenberger, S., Baccini, P., 1995. Acid neutralizing capacity of municipal waste incinerator bottom ash. Environ. Sci. Technol. 29, 142-147. https://doi.org/10.1021/es00001a018.

Katz, A., 2004. Treatments for the improvement of recycled aggregate. J. Mater. Civ. Eng. 16, 597-603. https://doi.org/10.1061/(ASCE)0899-1561(2004) 16:6(597).

Keawthun, M., Krachodnok, S., Chaisena, A., 2014. Conversion of waste glasses into sodium silicate solutions. Int. J. Chem. Sci. 12, 83-91.

Keulen, A., Van Zomeren, A., Harpe, P., Aarnink, W., Simons, H.A.E., Brouwers, H.J.H., 2016. High performance of treated and washed MSWI bottom ash granulates as natural aggregate replacement within earth-moist concrete. Waste Manag. 49, 83-95. https://doi.org/10.1016/j.wasman.2016.01.010.

Kim, H.K., Lee, H.K., 2011. Use of power plant bottom ash as fine and coarse aggregates in high-strength concrete. Constr. Build. Mater. 25, 1115-1122. https://doi.org/10.1016/j.conbuildmat.2010.06.065.

Kosson, D.S., van der Sloot, H.A., 1997. Intergration of testing protocols for evaluation of contaminant release from monolithic and granular wastes. Stud. Environ. Sci. 71, 201-215. https://doi.org/10.1016/S0166-1116(97)80204-X.

Kumar, D., Gupta, A., Ram, S., 2014. Uses of bottom ash in the replacement of fine aggregate for making concrete. Int. J. Curr. Eng. Technol. 4, 3891-3895.

Kunther, W., Ferreiro, S., Skibsted, J., 2017. Influence of the $\mathrm{Ca} / \mathrm{Si}$ ratio on the compressive strength of cementitious calcium-silicate-hydrate binders. J. Mater. Chem. A 5, 17401-17412. https://doi.org/10.1039/C7TA06104H.

Kutcharlapati, S., Sarkar, A.K., Rajamane, N.P., 2011. Nanosilica improves recycled concrete aggregates. NBM\&CW.

Lazaro, A., 2014. Nano-silica production at low temperatures from the dissolution of olivine - synthesis, tailoring and modelling.

Lewin, K., 1996. Leaching tests for waste compliance and characterisation: recent practical experiences. Sci. Total Environ. 178, 85-94. https://doi.org/10.1016/ 0048-9697(95)04800-6.

Li, J., Xiao, H., Zhou, Y., 2009. Influence of coating recycled aggregate surface with pozzolanic powder on properties of recycled aggregate concrete. Constr. Build. Mater. 23, 1287-1291. https://doi.org/10.1016/j.conbuildmat.2008.07.019.

Li, X.G., Lv, Y., Ma, B.G., Chen, Q. Bin, Yin, X.B., Jian, S.W., 2012. Utilization of municipal solid waste incineration bottom ash in blended cement. J. Clean. Prod. 32, 96-100. https://doi.org/10.1016/j.jclepro.2012.03.038.

Lo, T.Y., Cui, H.Z., 2004. Effect of porous lightweight aggregate on strength of concrete. Mater. Lett. 58, 916-919. https://doi.org/10.1016/j.matlet.2003.07.036.

Lynn, C.J., Dhir, O.B.E.R.K., Ghataora, G.S., 2016. Municipal incinerated bottom ash characteristics and potential for use as aggregate in concrete. Constr. Build. Mater. 127, 504-517. https://doi.org/10.1016/j.conbuildmat.2016.09.132. 
NEN-EN 6966, 2005. Milieu - Analyse van geselecteerde elementen in water, eluaten en destruaten - Atomaire emissiespectrometrie met inductief gekoppeld plasma. The Netherlands.

NEN 7345, 1995. Leaching characteristics of solid earthy and stony building and waste materials - Leaching tests - Determination of the leaching of inorganic components from buildings and monolitic waste materials with the diffusion test.

Newman, J., Choo, B.S., 2003. Advanced Concrete Technology 2: Concrete Properties. Elvisier.

Nocun-Wczelik, W., Malolepszy, J., 1997. Studies on immobilization of heavy metals in cement paste-CSH leaching behaviour. In: Proceeding of the International Congress on the Chemestry of Cement, Vol. 4.

Passuello, A., Rodríguez, E.D., Hirt, E., Longhi, M., Bernal, S.A., Provis, J.L., Kirchheim, A.P., 2017. Evaluation of the potential improvement in the environmental footprint of geopolymers using waste-derived activators. J. Clean. Prod. 166, 680-689. https://doi.org/10.1016/j.jclepro.2017.08.007.

Europe, P.Q., 2004. Sodium and potassium silicates. Soidium potasium Silic. versatile. Compd. your Appl. 2, 16.

Qiao, X.C., Ng, B.R., Tyrer, M., Poon, C.S., Cheeseman, C.R., 2008. Production of lightweight concrete using incinerator bottom ash. Constr. Build. Mater. 22, 473-480. https://doi.org/10.1016/J.CONBUILDMAT.2006.11.013.

Rossen, J.E., Lothenbach, B., Scrivener, K.L., 2015. Composition of C-S-H in pastes with increasing levels of silica fume addition. Cem. Concr. Res. 75, 14-22. https://doi.org/10.1016/j.cemconres.2015.04.016.

Saffarzadeh, A., Shimaoka, T., Wei, Y., Gardner, K.H., Musselman, C.N., 2011. Impacts of natural weathering on the transformation/neoformation processes in landfilled MSWI bottom ash: a geoenvironmental perspective. Waste Manage. 31, 2440-2454. https://doi.org/10.1016/j.wasman.2011.07.017.

Sallehan, I., Mahyuddin, R., 2014. A study on the effect of surface-treated coarse recycled concrete aggregate (RCA) on the compressive strength of concrete. Adv. Mater. Res. 935, 184-187. https://doi.org/10.4028/www.scientific.net/ AMR.935.184.

Scrivener, K.L., Crumbie, A.K., Laugesen, P., 2004. The interfacial transition zone (ITZ) between cement paste and aggregate in concrete. Interface Sci. 12, 411421. https://doi.org/10.1023/B:INTS.0000042339.92990.4c. van der Sloot, H.A., van der Wegenb, G.J.L., Hoedea, D., de Groot, G.J., 1994. 63 Intercomparison of Leaching Tests for Stabilized Waste. Environ. Asp. Constr. with waste Mater.

Soil Quality Decree [WWW Document], 2015. <http://wetten.overheid.nl/ BWBR0023085/BijlageA/geldigheidsdatum_09-10-2015>.

Spaeth, V., Djerbi-Tegguer, A., 2013. Treatment of recycled concrete aggregates by Si-based polymers. Waset. Org 7, 48-52.

Tang, P., Florea, M.V.A., Brouwers, H.J.H., 2017. Employing cold bonded pelletization to produce lightweight aggregates from incineration fine bottom ash. J. Clean Prod. 165, 1371-1384. https://doi.org/10.1016/j.jclepro.2017.07.234.

Tang, P., Florea, M.V.A., Spiesz, P., Brouwers, H.J.H., 2016. Application of thermally activated municipal solid waste incineration (MSWI) bottom ash fines as binder substitute. Cem. Concr. Compos. 70, 194-205. https://doi.org/10.1016/j. cemconcomp.2016.03.015.

Van Der Sloot, H.A., 1996. Developments in evaluating environmental impact from utilization of bulk inert wastes using laboratory leaching tests and field verification Waste Manag. 16, 65-81. https://doi.org/10.1016/S0956-053X(96)00028-1.

van der Sloot, H.A., Comans, R.N.J., Hjelmar, O., 1996. Similarities in the leaching behaviour of trace contaminants from waste, stabilized waste, construction materials and soils. Sci. Total Environ. 178, 111-126. https://doi.org/10.1016/ 0048-9697(95)04803-0.

Wongsa, A., Boonserm, K., Waisurasingha, C., Sata, V., Chindaprasirt, P., 2017. Use of municipal solid waste incinerator (MSWI) bottom ash in high calcium fly ash geopolymer matrix. J. Clean. Prod. 148, 49-59. https://doi.org/10.1016/j. jclepro.2017.01.147.

Wongsa, A., Zaetang, Y., Sata, V., Chindaprasirt, P., 2016. Properties of lightweight fly ash geopolymer concrete containing bottom ash as aggregates. Constr. Build. Mater. 111, 637-643. https://doi.org/10.1016/j.conbuildmat.2016.02.135.

Yao, J., Li, W., Xia, F., Wang, J., Fang, C., Shen, D., 2011. Investigation of Cu leaching from municipal solid waste incinerator bottom ash with a comprehensive approach. Front. Energy Power Eng. China 5, 340-348. https://doi.org/10.1007/ s11708-010-0131-9.

Zamorano, M., 2016. Study of potential advantages of pre-soaking on the properties of pre-cast concrete made with recycled coarse aggregate 66. 10.3989/ mc.2016.01715. 